\title{
FORMULATION AND EVALUATION OF MELOXICAM MICROSPHERES FOR COLON TARGETED DRUG DELIVERY
}

\section{SHRADHA KISHOR DHAS*, GANESH DESHMUKH}

\section{Department of Pharmaceutics, Oriental College of Pharmacy, Navi Mumbai, Maharashtra, India. Email: shradha.dhas@yahoo.com}

Received: 28 April 2021, Revised and Accepted: 07 June 2021

\section{ABSTRACT}

Objectives: The objective of this research was to organize and evaluate colon specific microspheres of the meloxicam for the treatment of colorectal cancer.

Methods: Sodium alginate microspheres were prepared by ionotropic gelation method using different ratios of meloxicam and sodium alginate (1:1, $1: 2$, and 1:3). Eudragit-coating of meloxicam, sodium alginate microspheres was performed by coacervation phase separation technique.

Results: The microspheres were characterized by shape, particle size, size distribution, incorporation efficiency, in vitro drug release studies and stability studies. The outer surfaces of the core and coated microspheres, which were spherical in shape, were rough and smooth, respectively. The size of the core microspheres ranged from 20 to $52 \mu \mathrm{m}$, and therefore the size of the coated microspheres ranged from 107 to $178 \mu \mathrm{m}$. The core microspheres sustained the discharge for $10 \mathrm{~h}$ during a $\mathrm{pH}$ progression medium mimicking the condition of gastrointestinal tract. The release studies of coated microspheres were performed during a similar dissolution medium as mentioned above. In acidic medium the discharge rate was much slower, however the drug was released quickly at pH 7.4 and their release was sustained up to $24 \mathrm{~h}$.

Conclusions: It's concluded from this investigation that Eudragit-coated sodium alginate microspheres are promising controlled release carriers for colon-targeted delivery of meloxicam.

Keywords: Meloxicam, Colon-specific, Microspheres, Sodium alginate, Eudragit S-100, Multiparticulate system.

(C) 2021 The Authors. Published by Innovare Academic Sciences Pvt Ltd. This is an open access article under the CC BY license (http://creativecommons.org/ licenses/by/4.0/) DOI: http://dx.doi.org/10.22159/ajpcr.2021v14i8.38482. Journal homepage: https://innovareacademics.in/journals/index.php/ajpcr

\section{INTRODUCTION}

Targeted drug delivery into the colon is highly desirable for local treatment of variety of bowel disease such as ulcerative colitis, cirrhosis disease, amoebiasis, colonic cancer, local treatment of colonic pathologies and systemic delivery of protein and peptide drugs. The colon specific drug delivery system should be a capable of protecting the drug in route to the colon, that is, drug release and absorption should not occur in stomach as well as in the small intestine, and neither the bioactive agent should be degraded either of the dissolution sites, but only released and absorbed once the system reaches the colon. A colonic targeted approach found to be effective in minimizing side effects $[1,2]$.

Epidemiological studies demonstrated that $40-50 \%$ reduction in the risk for colorectal cancer following prolonged use of non-steroidal antiinflammatory drugs. Recent studies show that cyclooxygenase (cox)-2 levels are increased in $85 \%$ of colorectal adenocarcinoma. Meloxicam is an non-steroidal anti-inflammatory drug drugs shows cox-1 IC50 of $3.27 \mu \mathrm{m}$ and cox-2 IC50 of $0.25 \mu \mathrm{m}, 13.1$ times more preferential for cox-2 inhibition. Evaluation of selective cox-2 inhibitors for effects on colorectal cancer are currently an area of intense investigation and preclinical studies have clearly shown potent antitumor properties and several studies are reported in the application of meloxicam for the prophylaxis of colorectal cancer $[3,4]$.

Various approaches were tried to achieve colonic delivery of drugs include use of prodrugs, $\mathrm{pH}$-sensitive polymer coatings, time dependent formulations, bacterial degradable coatings, time $/ \mathrm{pH}$-controlled delivers, and intestinal luminal pressure-controlled colon delivery capsules [5]. A well-designed controlled drug delivery system can overcome some of the problems of conventional therapy and enhance the therapeutic efficacy of a given drug. To obtain maximum therapeutic efficacy, it is necessary to deliver the agent to the target tissue in the optimal amount in the right period of time there by causing little toxicity and minimal side effects. There are various approaches in delivering a therapeutic substance to the target site in a sustained and controlled release fashion. One such approach is using microspheres as carriers for drugs. Microspheres are characteristically free flowing powders consisting of proteins or synthetic polymers which are biodegradable in nature and ideally having a particle size $<200 \mu \mathrm{m}[6,7]$.

Mainly colon-specific polymer-based matrix tablets are reported for meloxicam for colon targeting. However, due to variations in transit throughout the colon, the drug release is often impaired when the colonspecific tablet matrix isn't readily disintegrated, and treatment will remain ineffective. This problem might be circumvented by reducing the dimensions of the delivery carrier, since it's been reported that gastrointestinal retention depends on the dimensions of the carrier, meaning that smaller carriers will cause longer residence within the colon. Hence within the present investigation we are aimed to develop a colon-specific microsphere delivery system of meloxicam using natural and enteric polymer as a carrier and to develop the colon-specific delivery that has potential to be used as an adjuvant therapy for colorectal cancer.

\section{METHODS}

The meloxicam was supplied by yarrow chemicals; Sodium alginate was supplied by Thomas Baker; Eudragit S-100 Research lab; Calcium chloride and Hydrochloric Acid; n-hexane, Disodium hydrogen phosphate, Potassium di-hydrogen phosphate, Ethyl acetate Span 80 was supplied by S.D. Fine Mumbai.

Design and formulation of multiparticulate system of meloxicam Preparation of drug loaded sodium alginate microspheres

study In the present microspheres were prepared using sodium alginate as polymer by ionotropic gelation technique. The meloxicam 
was dispersed in a solution of $4 \% \mathrm{w} / \mathrm{v}$ sodium alginate with stirring to supply a viscous form. Then polymer drug solution was added drop wise using syringe of twenty-two $\mathrm{G}$ in diameter from a height of about $5 \mathrm{~cm}$ into a beaker containing $4 \% \mathrm{w} / \mathrm{v}$ solution of salt with continuous stirring by magnetic stirrer for $10 \mathrm{~min}$. Then the answer containing the gel formed microspheres was filtered using Whattman paper no1. The microspheres were allowed to dry at about $30-40^{\circ} \mathrm{C}$ and stored in well closed container for further use.

\section{Preparation of Eudragit S-100 coated sodium alginate microspheres}

Sodium alginate microspheres were coated with Eudragit S-100 using coacervation phase separation technique. Sodium alginate microspheres (50 mg) were dispersed in $10 \mathrm{ml}$ of coating solution prepared by dissolution of $200 \mathrm{mg}$ of Eudragit S100 in ethanol: acetone (2:1) to offer $1: 1,1: 2$, and $1: 3$ (coat: core ratio) and containing $0.2 \% \mathrm{w} / \mathrm{v}$ Span 80 . This mixture was agitated for $5 \mathrm{~min}$ at $600 \mathrm{rpm}$. Subsequently $50 \mathrm{ml} \mathrm{n}$-hexane (as the non-solvent) was poured into the polymeric solution containing the core material with the speed of $1 \mathrm{ml} / \mathrm{min}$. The medium was stirred for $60 \mathrm{~min}$ to finish the method of micro particles coating. Coated microspheres were then washed with a more than n-hexane, filtered and dried at room temperature [9].

\section{Evaluation of sodium alginate microspheres containing meloxicam} Characterization of beads

The developed microspheres beads were studied for compatibility studies by Fourier-transform infrared (FTIR) and subjected for various characterizations such as size and shape analysis, FTIR studies, percentage yield, incorporation efficiency, micrometric properties, degree of swelling, in vitro wash off test for microspheres.

\section{FTIR studies}

IR spectroscopic studies were carried out for prepared by meloxicam powder, using Shimadzu FTIR 1700 model to determine the integrity of the drug in the formulation.

\section{Compatibility studies}

Compatibility of the meloxicam with sodium alginate and Eudragit S-100 used to formulate microspheres was established by FTIR. Spectral analysis of meloxicam, sodium alginate and Eudragit S-100 and combination of the meloxicam with sodium alginate and Eudragit S-100 was carried out to investigate any changes in chemical composition of the drug after combining it with the excipients (Figs. 1-5).
Size and shape analysis

Microscopic analysis was performed to work out the typical size of microcapsules. The microcapsules prepared were dispersed in liquid paraffin and a drop of above dispersion was placed on a glass slide and observed under a microscope. The diameter of 100 microcapsules decided using calibrated eyepiece micrometre and stage micrometre. The typical diameter was calculated using the subsequent formula.

$$
\text { Average diameter }=\frac{\sum \text { nd }}{n} \times \text { c.f }
$$

Where

$\mathrm{n}=$ Number of micro beads

$\mathrm{d}=$ Diameter of the micro beads, C.F = Calibration factors.

Micrometric properties of alginate microspheres

The flow properties of coated microspheres were investigated by determining the angle of repose, bulk density, and tapped density. The angle of repose decided by the fixed base cone method. Bulk and tapped densities were measured in $10 \mathrm{ml}$ of a graduate. The sample contained within the cylinder was tapped mechanically by means of a constantvelocity rotating cam. The tapped volume was noted down when it showed no change in its value and bulk density and tapped density was calculated. Each experiment was performed 3 times [5].

\section{Determination of percentage yield of microspheres}

Thoroughly dried microspheres were collected and weighed accurately. The percentage yield was calculated using formula [10].

Percentage yield $=($ Practical yield $/$ Theoretical yield $) \times 100$.

\section{Incorporation efficiency}

In $100 \mathrm{ml}$ volumetric flask $20 \mathrm{mg}$ of crushed microspheres were taken and dissolved with small quantity of methanol of the volume is made up to mark with $\mathrm{pH} 6.8$ and stirred for $12 \mathrm{~h}$. After stirring the solution was filtered through Whatman filter paper and from the filtrate appropriate dilutions were made and absorbance was measured at $365 \mathrm{~nm}$ using UV-spectrophotometer 1700 (Shimadzu) [11].

Incorporation efficiency $=\mathrm{b} a \times 100$

Where "a" is the theoretical drug content and "b" is the drug entrapped. The incorporation efficiency of coated microspheres was determined as

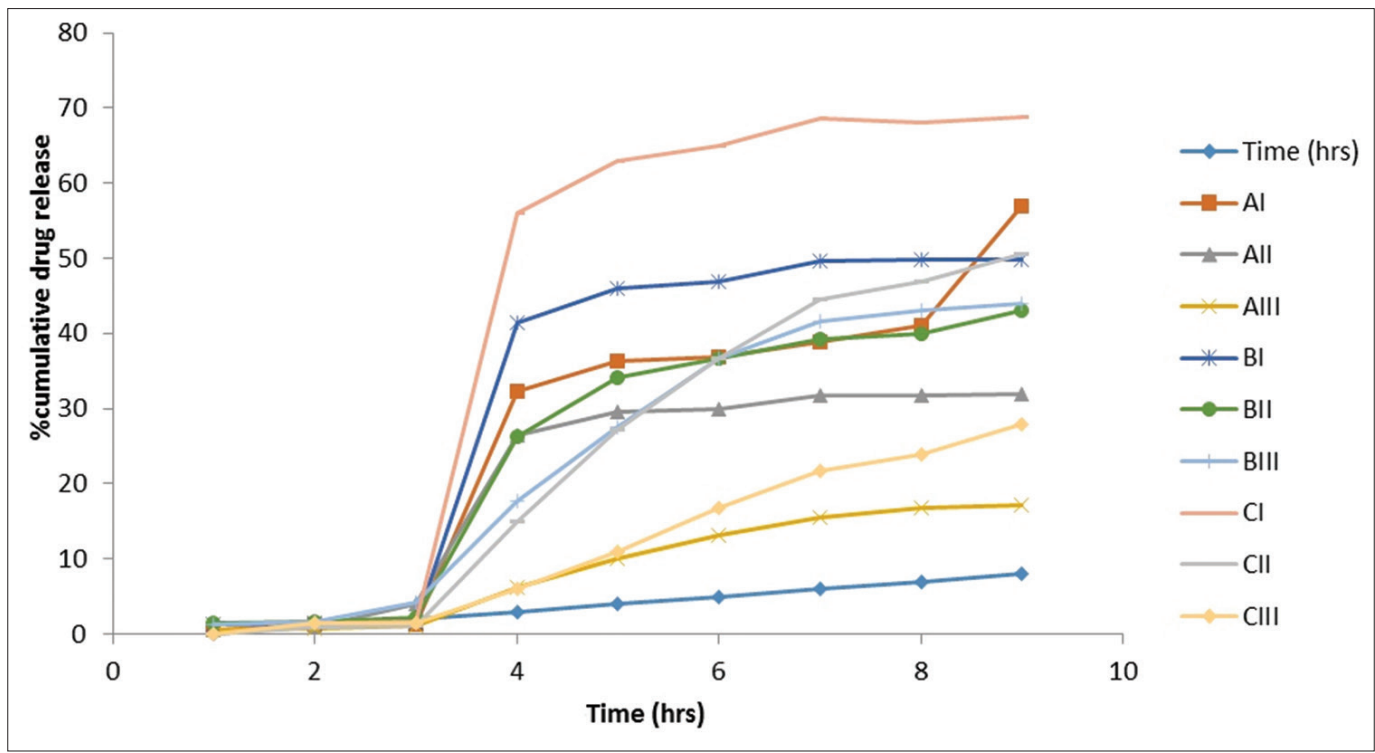

Fig. 1: 


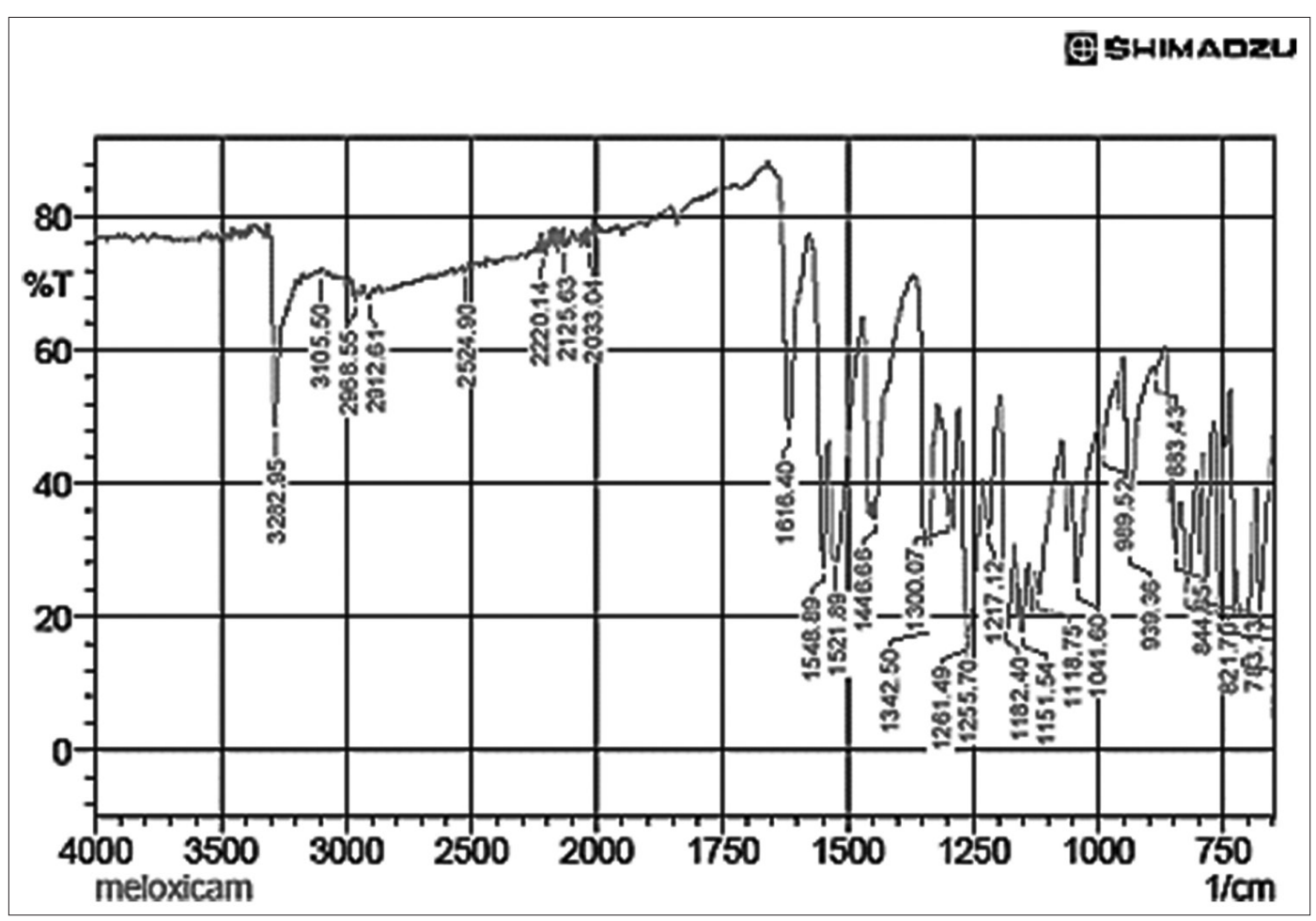

Fig. 2:

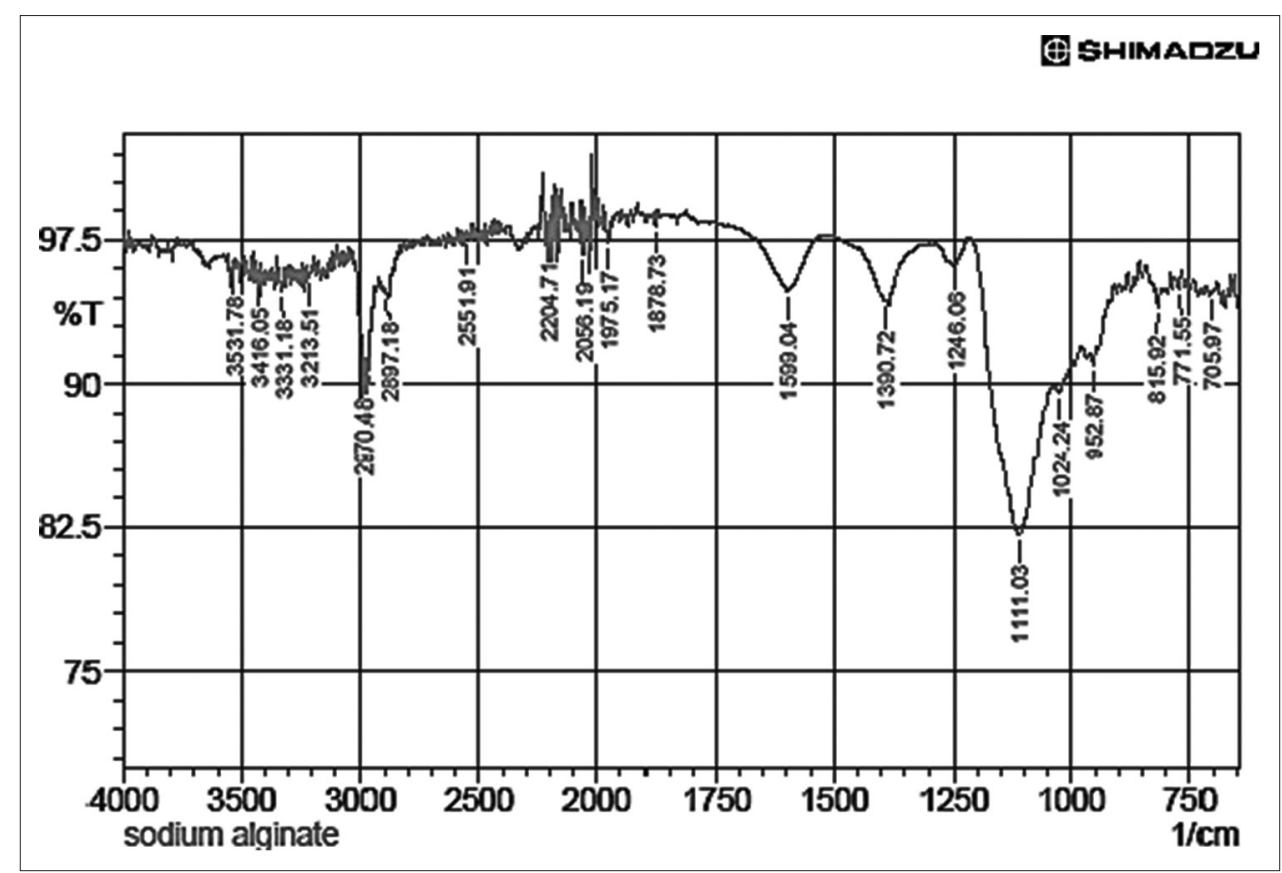

Fig. 3:

described above after removing the Eudragit S-100 coating by washing with methanol.

In vitro drug release studies of coated meloxicam microspheres

The release of meloxicam microsphere was carried out using USP basket-type dissolution apparatus at a rotation speed of $100 \mathrm{rpm}$, and a temperature of $37 \pm 0.5^{\circ} \mathrm{C}$. For Microsphere simulation of gastrointestinal transit conditions was achieved using different dissolution media. Thus, drug release studies were conducted in simulated gastric fluid (SGF, $\mathrm{pH}$ 1.2) for the first $2 \mathrm{~h}$ as the average gastric emptying time is about
$2 \mathrm{~h}$. Then, the dissolution medium was replaced with enzyme- free simulated intestinal fluid (SIF, pH 7.4) and tested for drug release for $3 \mathrm{~h}$, as the average small intestinal transit time is about $3 \mathrm{~h}$, and finally enzyme- free (SIF, $\mathrm{pH}$ 6.8) was used up to $8 \mathrm{~h}$ to mimic colonic $\mathrm{pH}$ conditions. About $900 \mathrm{ml}$ dissolution media was used. Medium $5 \mathrm{ml}$ of sample was withdrawn every time and replaced with fresh medium, samples withdrawn at various time intervals were analyzed spectrophotometrically at $365 \mathrm{~nm}$.

Kinetics of drug release experiments were treated with the different release kinetic equations $[14,15]$. 


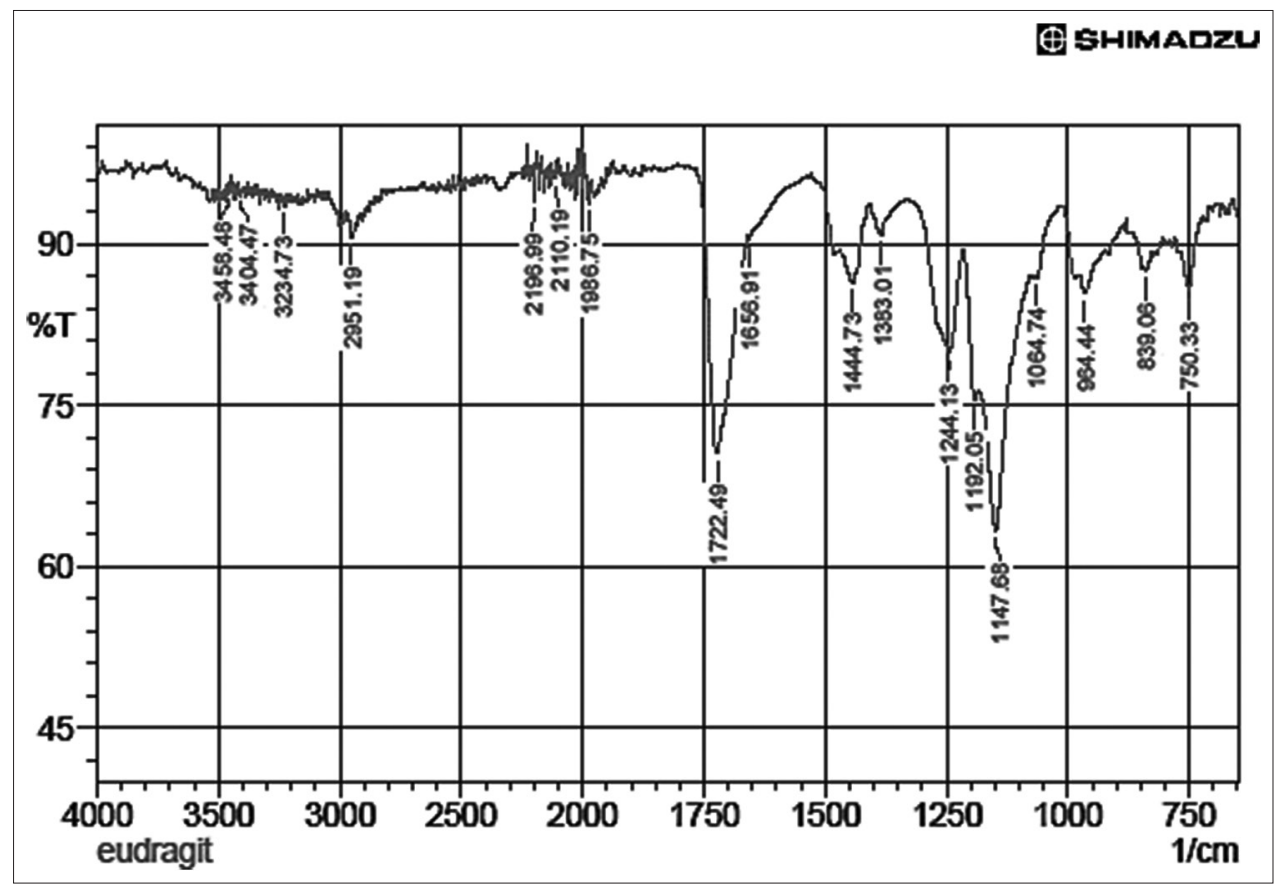

Fig. 4:

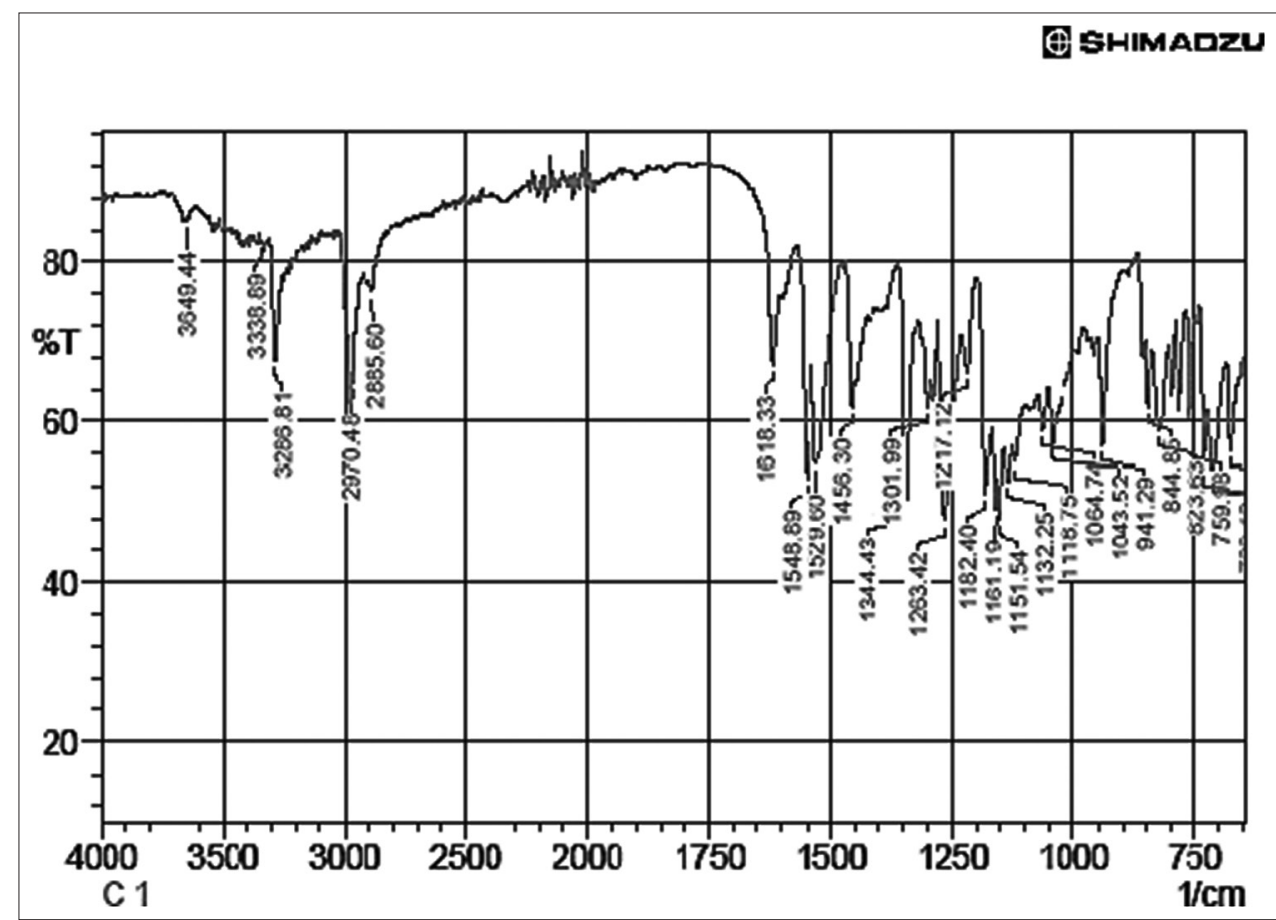

Fig. 5:

Zero order release equation:

$$
\mathrm{Q}=\mathrm{K} 0 \mathrm{t}
$$

First order equation:

$$
\text { In } \mathrm{Q}=\mathrm{Kf} \mathrm{t}
$$

Higuchi's square root of time equation:

$$
\mathrm{Q}=\mathrm{KH} \mathrm{t} 1 / 2
$$

Kors Meyer and Peppas equation:

$$
\mathrm{F}=(\mathrm{Mt} / \mathrm{M})=\mathrm{Km} \text { tn }
$$

\section{RESULTS AND DISSICUSION}

The aim of this project was to design and develop an oral, controlled release multi particulate drug delivery system of meloxicam proposed for colonic targeting. In this regard formulation studies were carried out. The results for the experiment conducted are as follows,

\section{Meloxicam sodium alginate microspheres}

Sodium alginate microspheres of meloxicam were successfully prepared by ionotropic gelation method. Uniform and almost spherical microspheres were obtained. The mean diameter of sodium alginate microspheres varied with varying drug: polymer ratio (AI, AII, III, BI, BII, BIII, CI, CII, and CIII). The results were shown in Table 1.

\section{Compatibility studies}

From the FT-IR spectra of the pure drug and therefore the combination spectra of drug with the polymers, it had been observed that each 
Table 1: Formulation plan

\begin{tabular}{|c|c|c|c|c|c|c|c|c|c|}
\hline Ingredient & AI & AII & AIII & BI & BII & BIII & CI & CII & CIII \\
\hline Meloxicam & $2 \mathrm{~g}$ & $2 \mathrm{~g}$ & $2 \mathrm{~g}$ & $2 \mathrm{~g}$ & $2 \mathrm{~g}$ & $2 \mathrm{~g}$ & $2 \mathrm{~g}$ & $2 \mathrm{~g}$ & $2 \mathrm{~g}$ \\
\hline Sodium alginate & $1 \mathrm{~g}$ & $1 \mathrm{~g}$ & $1 \mathrm{~g}$ & $2 \mathrm{~g}$ & $2 \mathrm{~g}$ & $2 \mathrm{~g}$ & $3 \mathrm{~g}$ & $3 \mathrm{~g}$ & $3 \mathrm{~g}$ \\
\hline Calcium chloride & $2 \mathrm{~g}$ & $2 \mathrm{~g}$ & $2 \mathrm{~g}$ & $2 \mathrm{~g}$ & $2 \mathrm{~g}$ & $2 \mathrm{~g}$ & $2 \mathrm{~g}$ & $2 \mathrm{~g}$ & $2 \mathrm{~g}$ \\
\hline Eudragit s 100 & $100 \mathrm{mg}$ & $200 \mathrm{mg}$ & $300 \mathrm{mg}$ & $100 \mathrm{mg}$ & $200 \mathrm{mg}$ & $300 \mathrm{mg}$ & $100 \mathrm{mg}$ & $200 \mathrm{mg}$ & $300 \mathrm{mg}$ \\
\hline ethanol & $7 \mathrm{ml}$ & $7 \mathrm{ml}$ & $7 \mathrm{ml}$ & $7 \mathrm{ml}$ & $7 \mathrm{ml}$ & $7 \mathrm{ml}$ & $7 \mathrm{ml}$ & $7 \mathrm{ml}$ & $7 \mathrm{ml}$ \\
\hline acetone & $3 \mathrm{ml}$ & $3 \mathrm{ml}$ & $3 \mathrm{ml}$ & $3 \mathrm{ml}$ & $3 \mathrm{ml}$ & $3 \mathrm{ml}$ & $3 \mathrm{ml}$ & $3 \mathrm{ml}$ & $3 \mathrm{ml}$ \\
\hline Span 80 & $0.1 \mathrm{ml}$ & $0.1 \mathrm{ml}$ & $0.1 \mathrm{ml}$ & $0.1 \mathrm{ml}$ & $0.1 \mathrm{ml}$ & $0.1 \mathrm{ml}$ & $0.1 \mathrm{ml}$ & $0.1 \mathrm{ml}$ & $0.1 \mathrm{ml}$ \\
\hline
\end{tabular}

one the characteristics peaks of meloxicam, were present within the combination spectra thus indicating the compatibility of the drug with the polymers used. The individual spectra of the pure drug meloxicam, polymer sodium alginate, Eudragit S-100 also because the combination of the drug and polymers are shown within the Figs. 3-5 respectively. For finding out the mechanism of drug release from tablets, the dissolution data obtained from the above experiments were treated with the various release kinetic equations [14,15].

Zero order release equation:

$$
\mathrm{Q}=\mathrm{K} 0 \mathrm{t}
$$

First order equation:

$$
\text { In } \mathrm{Q}=\mathrm{Kf} \mathrm{t}
$$

Higuchi's square root of time equation:

$$
\mathrm{Q}=\mathrm{KH} \mathrm{t} \mathrm{t}^{1 / 2}
$$

Kors Meyer and Peppas equation:

$$
\mathrm{F}=(\mathrm{Mt} / \mathrm{M})=\mathrm{Km} \mathrm{tn}
$$

Morphology, size of microspheres, and micrometric properties of microspheres

The sodium alginate microspheres were discrete and spherical in shape with a rough outer surface due to the surface-associated crystals of the drug. Table 2 indicates that a better ratio of drug and polymer is related to increase in microsphere size decrease within the alginate concentration resulted within the clumping of microspheres, whereas a better sodium alginate concentration resulted within the formation of discrete microspheres with a mean diameter of $78 \mu \mathrm{m}$. This might flow from to higher viscosity at a better concentration and formation of larger microspheres. This might be explained by the very fact that more of the calcium ions became available for cross-linking guluronic acid units of sodium alginate, leading to the formation of more crosslinked alginate, which successively could increase the viscosity of the formulation, resulting in the formation of larger microspheres. The diameter of the core microspheres was in the range of 20-52 $\mu \mathrm{m}$. A scanning microscopy photograph of coated alginate microspheres showed that the microspheres were discrete and spherical in shape, with a smooth outer surface. The dimensions of coated microspheres ranged from $107 \mu \mathrm{m}$ to $178 \mu \mathrm{m}$. All formulations showed excellent flowability, as represented in terms of angle of repose (Table 3).

\section{In vitro drug release studies for uncoated microspheres}

The in vitro release profile of different core alginate microsphere formulations in there was no significant difference in rate and extent of drug releases from formulations and statically significant difference within the rate and extent of drug release was observed in formulation compared to different ratio of formulations. This might be attributed to a rise within the density of the polymer matrix and therefore the diffusional path length that the drug has got to transverse. The discharge of meloxicam was characterized by a burst release followed by a moderate, slow release. The biphasic pattern of drug release is characteristic of matrix diffusion kinetics. The burst release are often reduced by increasing the polymer concentration, leading to better incorporation efficiency, as discussed earlier, and a decrease in surface associated drug. The results indicate that rate and extent of drug release decreased significantly.
Table 2: Physical characteristics of core and coated microspheres

\begin{tabular}{llllll}
\hline $\begin{array}{l}\text { Batch } \\
\text { Angle of } \\
\text { repose }\end{array}$ & Bulk & Tensity & Tapped & \multicolumn{2}{l}{ Hausner's $\%$} \\
density & ratio & Compressibility \\
\hline AI & $26.85 \pm 0.24$ & $0.58 \pm 0.04$ & $0.63 \pm 0.03$ & $1.08 \pm 0.05$ & $7.93 \pm 0.34$ \\
AII & $24.22 \pm 0.29$ & $0.60 \pm 0.03$ & $0.66 \pm 0.02$ & $1.11 \pm 0.06$ & $9.09 \pm 0.16$ \\
AIII & $27.60 \pm 0.16$ & $0.56 \pm 0.02$ & $0.59 \pm 0.03$ & $1.15 \pm 0.03$ & $5.08 \pm 0.08$ \\
BI & $28.98 \pm 0.33$ & $0.52 \pm 0.01$ & $0.58 \pm 0.02$ & $1.11 \pm 0.03$ & $10.34 \pm 0.32$ \\
BII & $27.15 \pm 0.24$ & $0.67 \pm 0.03$ & $0.73 \pm 0.01$ & $1.09 \pm 0.05$ & $8.22 \pm 0.14$ \\
BIII & $28.05 \pm 0.20$ & $0.62 \pm 0.02$ & $0.70 \pm 0.03$ & $1.12 \pm 0.04$ & $11.42 \pm 0.22$ \\
CI & $29.56 \pm 0.40$ & $0.56 \pm 0.02$ & $0.62 \pm 0.02$ & $1.10 \pm 0.05$ & $9.96 \pm 0.22$ \\
CII & $28.14 \pm 0.14$ & $0.65 \pm 0.04$ & $0.75 \pm 0.02$ & $1.10 \pm 0.04$ & $8.90 \pm 0.29$ \\
CIII & $29.34 \pm 0.39$ & $0.62 \pm 0.02$ & $0.69 \pm 0.02$ & $1.20 \pm 0.05$ & $6.25 \pm 0.18$ \\
\hline
\end{tabular}

In vitro drug release studies for coated microspheres

The second a part of the formulation focused on coated alginate core microspheres. The cores were microencapsulated by the coacervation phase separation technique. The coating polymer, Eudragit S-100, dissolves above $\mathrm{pH}$ 7.0, thereby protecting the drug from releasing from the alginate core before reaching the colonic region. Once the enteric coating dissolves, it's expected that drug release would then be controlled by alginate within the target. The in vitro release behaviour of encapsulated microspheres was very dramatic needless to say, no drug release occurred at gastric 1.2 for $2 \mathrm{~h}$. As shown in Fig. 1, no drug release occurred below the $\mathrm{pH}$ of polymer solubility. After this lag time, drug release and therefore the time for the entire drug varied counting on the core-to-coat ratio. The discharge of meloxicam bogged down because the concentration of coating polymer increased. The in vitro release studies data were fitted into various release equations to elucidate the kinetics of drug release from these microspheres. The kinetic models used were first-order, zero-order, Higuchi and Peppas release models. Linear regressions are shown for maximum drug release batch. The examination of the determination R2 coefficient indicated that drug release followed the diffusion control mechanism from the core and coated microspheres. To explore the kinetic behavior, in vitro release results were further fitted into the subsequent Kors Meyer and Peppas equation.

$\mathrm{Mt} M \infty=\mathrm{K}$ tn

Where $\mathrm{Mt} / \mathrm{M} \infty$ is the fraction of drug time $\mathrm{t}, \mathrm{k}$ is a kinetic constant, and $\mathrm{n}$ is a release exponent that characterizes the drug transport.

\section{In vitro drug release for coated microspheres}

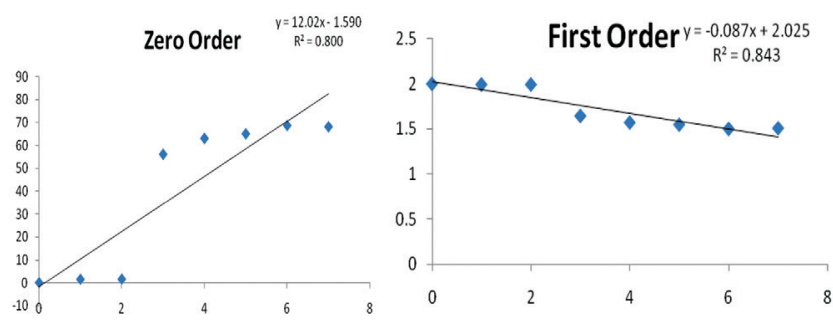


Table 3: Drug release profile of meloxicam by dissolution apparatus

\begin{tabular}{|c|c|c|c|c|c|c|c|c|c|}
\hline Time interval formulation & $0 \mathrm{~h} 1.2 \mathrm{pH}$ & $1 \mathrm{~h} 1.2 \mathrm{pH}$ & $2 \mathrm{~h} 1.2 \mathrm{pH}$ & $3 \mathrm{~h} 7.4 \mathrm{pH}$ & $4 \mathrm{~h} 7.4 \mathrm{pH}$ & 5 h 7.4pH & $6 \mathrm{~h} 6.8 \mathrm{pH}$ & $7 \mathrm{~h} 6.8 \mathrm{pH}$ & $8 \mathrm{~h} 6.8 \mathrm{PH}$ \\
\hline $\mathrm{AI}$ & 0.61 & 1.22 & 1.34 & 32.32 & 36.36 & 36.82 & 38.84 & 40.98 & 56.91 \\
\hline AII & 0.46 & 0.93 & 4.09 & 26.39 & 29.64 & 29.88 & 31.72 & 31.75 & 31.90 \\
\hline AIII & 0.61 & 0.66 & 1.07 & 6.28 & 9.99 & 13.21 & 15.58 & 16.76 & 17.19 \\
\hline BI & 1.35 & 1.37 & 1.43 & 41.39 & 45.99 & 46.94 & 49.56 & 49.77 & 49.80 \\
\hline BII & 1.46 & 1.65 & 2.26 & 26.34 & 34.21 & 36.60 & 39.29 & 40.05 & 42.98 \\
\hline BIII & 1.35 & 1.59 & 4.24 & 17.73 & 27.53 & 36.61 & 41.59 & 43.12 & 43.90 \\
\hline CI & 1.40 & 1.48 & 1.55 & 56.09 & 63.02 & 65.00 & 68.67 & 68.10 & 68.78 \\
\hline CIII & 1.35 & 1.40 & 1.54 & 5.99 & 10.99 & 16.76 & 21.63 & 23.98 & 27.87 \\
\hline
\end{tabular}

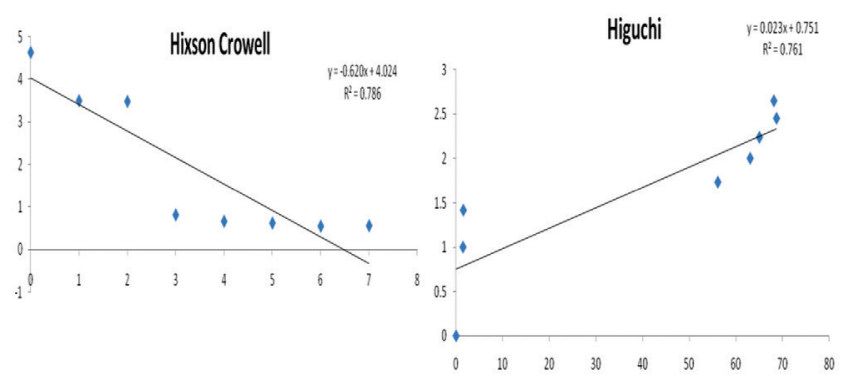

Koresemeyer Peppas

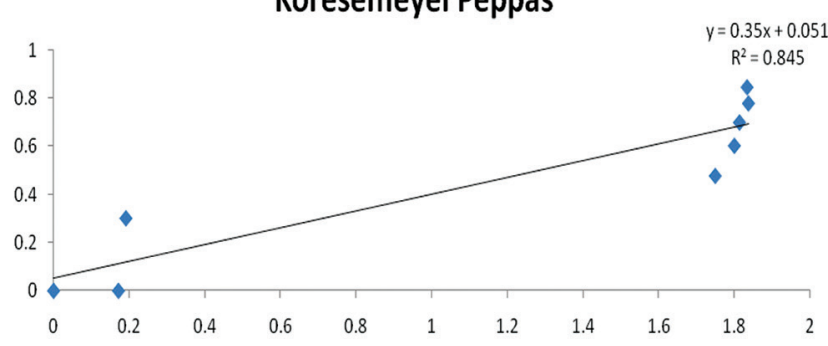

Factorial design

\begin{tabular}{|c|c|c|c|}
\hline \multicolumn{4}{|c|}{ Factorial of batches } \\
\hline \multirow[t]{2}{*}{ Run } & Factor 1 & Factor 2 & Response 1 \\
\hline & $\begin{array}{l}\text { A:Sodium } \\
\text { alginate (g) }\end{array}$ & $\begin{array}{l}\text { B:Eudragit } \\
\text { S-100 (mg) }\end{array}$ & CPR (\%) \\
\hline 1 & 1 & 100 & 56.91 \\
\hline 2 & 1 & 200 & 31.9 \\
\hline 3 & 1 & 300 & 17.19 \\
\hline 4 & 2 & 100 & 49.8 \\
\hline 5 & 2 & 200 & 42.98 \\
\hline 6 & 2 & 300 & 43.9 \\
\hline 7 & 3 & 100 & 68.79 \\
\hline 8 & 3 & 200 & 50.47 \\
\hline 9 & 3 & 300 & 27.87 \\
\hline
\end{tabular}

Response 1 CPR

ANOVA for Response Surface Linear model

Analysis of variance table (Partial sum of squares - Type III)

\begin{tabular}{|c|c|c|c|c|c|c|}
\hline Source & $\begin{array}{l}\text { Sum of } \\
\text { Squares }\end{array}$ & df & $\begin{array}{l}\text { Mean } \\
\text { square }\end{array}$ & $\begin{array}{l}\text { F } \\
\text { value }\end{array}$ & $\begin{array}{l}\text { p-value } \\
\text { Prob }>\text { F }\end{array}$ & \\
\hline Model & 1530.14 & 2 & 765.07 & 10.23 & 0.0117 & Significant \\
\hline $\begin{array}{l}\text { A-Sodium } \\
\text { alginate }\end{array}$ & 281.95 & 1 & 281.95 & 3.77 & 0.1002 & \\
\hline $\begin{array}{l}\text { B-Eudragit } \\
\text { S-100 }\end{array}$ & 1248.20 & 1 & 1248.20 & 16.69 & 0.0065 & \\
\hline Residual & 448.73 & 6 & 74.79 & & & \\
\hline Cor Total & 1978.87 & 8 & & & & \\
\hline
\end{tabular}

The Model F-value of 10.23 implies the model is significant. There is only a $1.17 \%$ chance that an F-value this large could occur due to noise. Values of "Prob $>F$ " $<0.0500$ indicate model terms are significant. In this case B is a significant model term. Values $>0.1000$ indicate the model terms are not significant.If there are many insignificant model terms (not counting those required to support hierarchy), model reduction may improve your model.

\begin{tabular}{llll}
\hline SD & 8.65 & R-Squared & 0.7732 \\
Mean & 43.31 & Adj R-Squared & 0.6977 \\
C.V\% & 19.97 & Pred R-Squared & 0.4721 \\
PRESS & 1044.68 & Adeq Precision & 8.523 \\
-2 Log Likelihood & 60.72 & BIC & 67.32 \\
& & AICc & 71.52 \\
\hline
\end{tabular}

The "Pred R-Squared" of 0.4721 is not as close to the "Adj R-Squared" of 0.6977 as one mightnormally expect; that is, the difference is more than 0.2 . This may indicate a large block effector a possible problem with your model and/or data. Things to consider are model reduction, response transformation, outliers, etc. All empirical models should be tested by doing confirmation runs. "Adeq Precision" measures the signal to noise ratio. A ratio $>4$ is desirable. Your ratio of 8.523 indicates an adequate signal. This model can be used to navigate the design space.

\begin{tabular}{|c|c|c|c|c|c|c|}
\hline \multirow[t]{2}{*}{ Factor } & \multirow{2}{*}{$\begin{array}{l}\text { Coefficient } \\
\text { estimate }\end{array}$} & \multirow{2}{*}{ df } & \multirow{2}{*}{$\begin{array}{l}\text { Standard } \\
\text { error }\end{array}$} & \multirow{2}{*}{$\frac{95 \% \mathrm{CI}}{\text { Low }}$} & \multirow{2}{*}{$\begin{array}{l}95 \% \text { CI } \\
\text { High }\end{array}$} & \multirow[t]{2}{*}{ VIF } \\
\hline & & & & & & \\
\hline Intercept & 43.31 & 1 & 2.88 & 36.26 & 50.37 & \\
\hline $\begin{array}{l}\text { A-Sodium } \\
\text { alginate }\end{array}$ & 6.86 & 1 & 3.53 & -1.78 & 15.49 & 1.00 \\
\hline $\begin{array}{l}\text { B-Eudragit } \\
\text { S-100 }\end{array}$ & -14.42 & 1 & 3.53 & -23.06 & -5.78 & 1.00 \\
\hline
\end{tabular}

Final equation in terms of coded factors

$\mathrm{CPR}=+43.31+6.86^{*} \mathrm{~A}-14.42 * \mathrm{~B}$

The equation in terms of coded factors can be used to make predictions about the response forgiven levels of each factor. By default, the high levels of the factors are coded as +1 and the low levels of the factors are coded as -1 . The coded equation is useful for identifying the relative impact of the factors by comparing the factor coefficients.

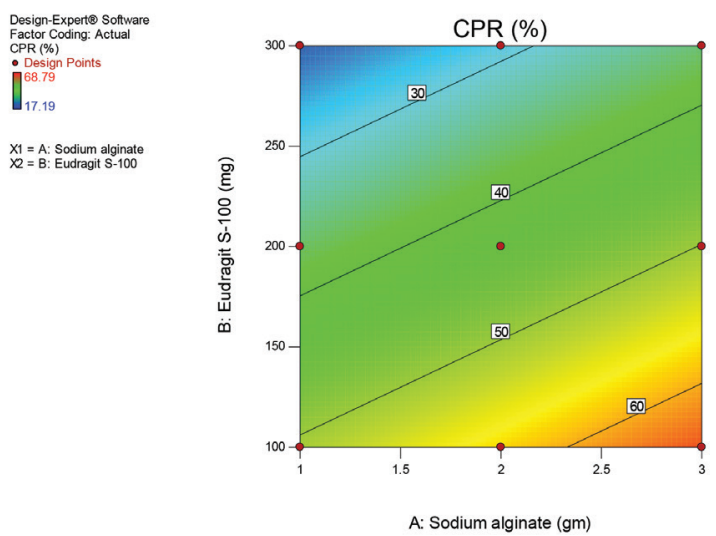



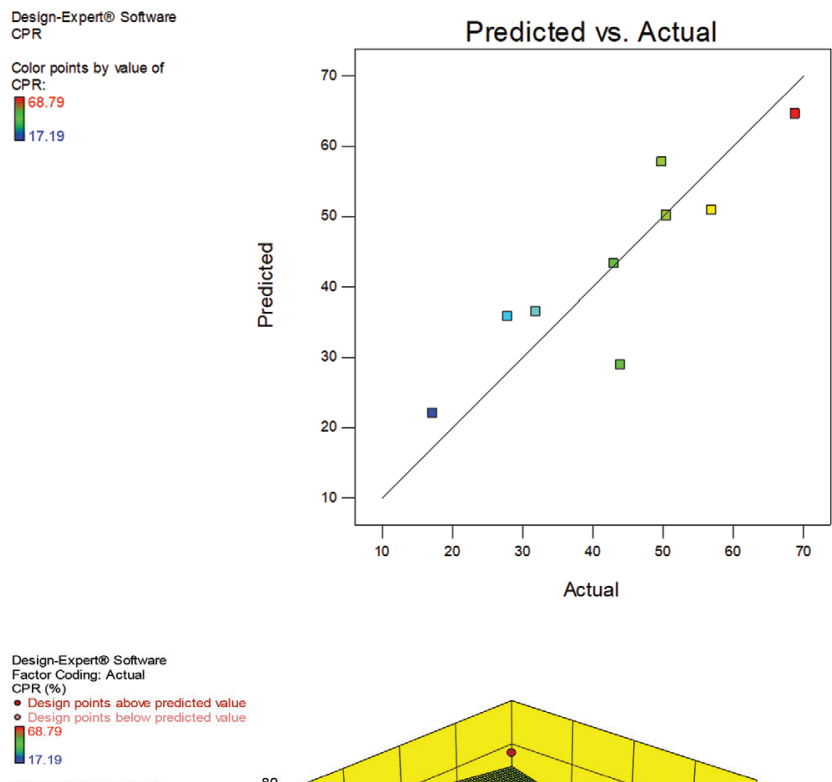

$\mathrm{X} 1=\mathrm{A}:$ Sodium alginate
$\mathrm{X} 2=\mathrm{B}:$ Eudragit $\mathrm{S}-100$

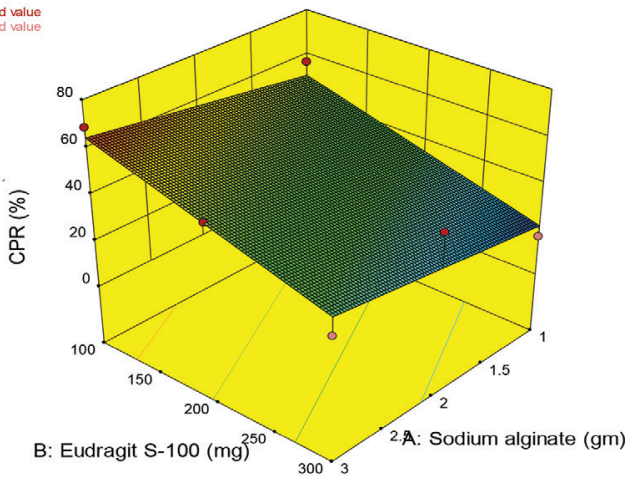

\section{CONCLUSIONS}

The results of my study clearly indicate that there is great potential in delivery of meloxicam to the colonic region as an alternative to the conventional dosage form. However, more extensive pharmacokinetic and pharmacodynamics studies are needed before establishing colonic delivery of meloxicam as an alternative. Sodium alginate is a biocompatible polymer; we expect it to cause no harmful effects if used for prolonged periods.

\section{ACKNOWLEDGMENT}

I would like to thank to Mr. Ganesh Deshmukh, Assistant professor, Oriental College of Pharmacy for giving excellent support in carrying out this research work.

\section{AUTHORS' CONTRIBUTIONS}

The authors have made considerable contributions to the work reported in the manuscript.

\section{CONFLICTS OF INTEREST}

The authors confirm that this article content has no conflicts of interest.

\section{AUTHORS FUNDING}

Not applicable.

\section{REFERENCES}

1. Asha P, Nilam B, Patel KR, Patel NM, Patel M. Colon targeted drug delivery system. J Pharm Sci Bio Res 2011;1:37-49.

2. Akala EO, Elekwachi O, Chase V, Johnson H, Marjorie L, Scott K. Organic redox-initiated polymerization process for the fabrication of hydrogels for colon-specific drug delivery. Drug Dev Ind Pharm 2003;29:375-86

3. Goldman AP, Williams CS, Sheng H, Lamps LW, Williams VP, Pairet M, et al. Meloxicam inhibits the growth of colorectal cancer cells. Carcinogenesis 1998;19:2195-9.

4. Theen MJ, Namboodiri MM, Calle EE, Flandeus WD, Health CW Jr. Aspirin use and risk of fatal cancer. Cancer Res 1993;53:1322-7.

5. Kumar BS, Saravanakumar M, Thirumurthy R. Formulation and evaluation of celecoxib microspheres by using ethyl cellulose and eudragit S-100 in colon drugs delivery. Pharma Chem 2010;2:322-8.

6. Chaturvedi G, Saha RN. A review on microsphere technology and its application. Birla Inst Technol Sci 2009;1:56-8.

7. Katariashail, Middha A, Sandhu P, Ajay B. Microsphere. Int J Res Pharm 2011;1:1184-97.

8. Mazumder R, Nath LK, Haque A, Maity T, Choudhury PK, Shrestha B, et al. Formulation and in vitro evaluation of natural polymers based microspheres for colonic drug delivery. Int J Pharm Pharm Sci 2010;2:211-9.

9. Fatemeh A, Rudabeh V, Rassoul D. Preparation of ethylcellulose coated gelatin microspheres as a multiparticulate colonic delivery system for 5-aminosalicilic acid. Ira J Pharm Res 2004;2:81-6.

10. Ghodke DS, Naikwade NS. Optimization of spray drying parameters for preparation of chitosan microspheres of oxidizing pharmaceutical active. J Pharm Res 2010;3:1752-5.

11. Kothawade KB, Gattani SG, Surana SJ, Amrutkar JR. Colonic delivery of aceclofenac using combination of $\mathrm{pH}$ and time dependent polymers. Indian Drugs 2009;46:67-70.

12. Mastiholimath VS, Dandagi PM, Jain SS, Gadad AP, Kulkarni AR. Time and $\mathrm{pH}$ dependent colon specific, pulsatile delivery of theophylline for nocturnal asthma. Int J Pharm 2007;328:49-56.

13. Lachman L, Liberman HA, Kanig JL, Bakan JA. The Theory and Practice of Industrial Pharmacy. $3^{\text {rd }}$ ed. Bombay: Varghese Publishing House; 1991. p. 67.

14. Nasra MA, EL-Massik MA, Nagger VF. Development of metronidazole colon-specific delivery systems. Asian J Pharm Sci 2007;2:18-28.

15. Anekant J, Yashwant G, Sanjay KJ. Perspectives of biodegradable natural polysaccharides for site-specific drug delivery to the colon. J Pharm Pharm Sci 2007;10:86-128. 